\title{
Effect of Wage, Inflation and Exchange Rate on the Investment Policy in Sidoarjo District, Indonesia
}

\author{
Priyono $^{1}$ (D)
}

Received: 12 July 2017 / Accepted: 18 June 2018 /Published online: 7 August 2018

(C) The Author(s) 2018

\begin{abstract}
The purpose of this study is to know and analyze the effect of wage variables on regional investment policy, the influence of inflation variables on regional investment policy, and the influence of exchange rate variables on investment policy of the Region on Labor. In this study, the population taken is the entire workforce whose data comes from the Central Bureau of Statistics in Sidoarjo which amounted to 64,792 workers. Data analysis using multiple linear regressions with the help of SPSS program version 20 showed that there is an influence of wages, inflation, and exchange rate on local investment policy. Based on the results of calculations and test results conducted, it can be explained that there is an effect of wages on regional investment of labor followed by the characteristics of inflation on labor that affects the exchange rate of investment. This illustrates for policymakers which empirical evidence exists in a series of time to test the theoretical basis while establishing fiscal, monetary, or exchange rate policies to stabilize output and employment by using interest rates, money supply, and exchange rates as instruments for achieving goals.
\end{abstract}

Keywords Wages $\cdot$ Inflation $\cdot$ Exchange rates $\cdot$ Investment policy

\section{Introduction}

Sidoarjo Regency is one of the districts closest to the capital of East Java Province, namely Surabaya. Sidoarjo is a large industrial area; this is indicated by the establishment of national and international factories located in this region. So, in Sidoarjo, there are workers who number thousands.

An early study in Mexico, the USA, and Venezuela [1,2] compares the average wage between domestic and foreign firms. They point out that the average wage of

Priyono

priyono.unu_sidoarjo@yahoo.com

1 Universitas Bina Darma, Jl. A. Yani No. 3, Palembang, Sumatra Selatan, Indonesia 
foreign-owned plants tends to be about 30\% higher than that of domestic-owned factories. However, this does not mean that the ownership of foreign factories can improve the labor conditions in the country, since labor in domestic and foreign companies may differ qualitatively. This study was conducted to address the possibility that the average wage differential between foreign and domestic firms only reflects differences in the composition of the labor force.

A number of other studies, analyzing the extent to which foreign premade wages persist domestically, for example [19, 20], use datasets in Indonesia with detailed information on the composition of workers across the education category. They found a difference in the average quality of labor that is an important part of providing wage standards in foreign-owned plants that are currently $12 \%$ higher for production workers and $20 \%$ for non-production workers. Reference [24] presents similar findings for five sub-Saharan African countries.

In addition, Sidoarjo is one of the districts that has a relatively large number of workers, as well as a larger city minimum wage, when compared to other districts. It is recorded that about 10,000 Sidoarjo residents compose the workforce [7].

Figure 1 is a graphic image of the first development of Indonesia from 2006 to 2016 and Table 1 shows the inflation rate (annual\% change on consumer price index):

\section{Traditional Peak Inflation in Indonesia}

[26] states that there are two peaks of traditional annual inflation in Indonesia. The December-January period always brings higher prices due to Christmas and New Year celebrations, while traditional flooding in January (in the middle of the peak of the rainy season) results in disruption of distribution channels in some areas and cities, resulting in higher logistics costs. The peak of the second inflation occurred in the period July-August. The inflationary pressure in these two months emerged as a result of holiday periods, Muslim holy fasting month (Ramadhan), Eid Al-Fitr celebrations, and commencement of the new school year. Significant increases can be detected in spending on food and other consumables (such as clothing, bags, and shoes), along with retailers adjusting prices up.

From the theoretical side, there is much controversy over whether the rate of output growth is influenced by demand-side factors in the short term because wage

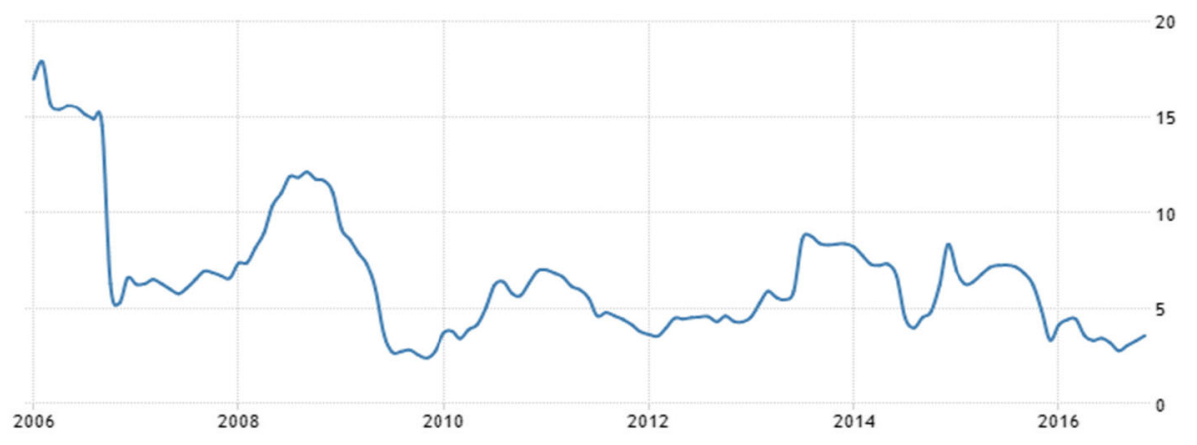

Sources: www.tradingeconomics.com \& Statistics Indonesia (BPS)

Fig. 1 The development of Indonesia in 2015-2016 
Table 1 Indonesian inflation per component (\%)

\begin{tabular}{llll}
\hline Indicator & 2014 & 2015 & 2016 \\
\hline Food & 10.57 & 4.93 & 5.69 \\
Instant food, beverages, cigarettes, and tobacco & 8.11 & 6.42 & 5.38 \\
Housing, water, electricity, gas, and fuel & 7.36 & 3.34 & 1.90 \\
Clothing & 3.08 & 3.43 & 3.05 \\
Health & 5.71 & 5.32 & 3.92 \\
Education, recreation, and sports & 4.44 & 3.97 & 2.73 \\
Transportation, communication, and financial services & 12.40 & -1.52 & -0.72 \\
\hline
\end{tabular}

Source: Statistics Indonesia (BPS)

contracts and asymmetric information extend adjustments to long-run equilibrium as studied by [10], regardless of unanimity among economists about the role of supply-side factors such as physical and human capital and technology to growth over the long term.

New Keynesian and Keynesian models show a positive impact of money in growth and employment levels that are different from the neutrality of money in new classic and classic models [9]. For policymakers, the empirical evidence contained in the time series as given in Fig. 1 is to test the theoretical basis while establishing fiscal, monetary, or exchange rate policies to stabilize output and employment by using interest rates, money supply, and value exchange as an instrument to achieve that goal [22]. Establishing the right relationship between stabilization goals and fiscal and monetary policy instruments is a major contribution to simultaneous macroeconometric equations modeling in the literature for this purpose $[11,12,14,15,30,33-35]$.

Benefits such as increased productivity may also depend heavily on the sector invested, and the host country environment [17] in his study mentioned that imported affiliate technology is increasing with the host country's domestic investment and education level. Therefore, productivity benefits may rely heavily on the investment sector, technological gaps in certain investments, and host country environments. However, [30] claims [8] that emphasized monetary factors at the expense of supply factors in Ghana and concluded that supply constraints are the main force behind inflation.

In addition, inflation distorts the tax system, and investors feel uncomfortable because of the illusion of money. Inflation rate is positively correlated with its volatility. Greater fluctuations in inflation are consistent with higher rates of inflation and therefore increase uncertainty and impede long-term investment [27]. However, inflation also has economic benefits. This benefit depends on three main arguments in favor of positive inflation. First, there is a trade-off between inflation, taxes, and other indirect taxes so that the optimization of government taxes means positive inflation. Second, there is a commitment of policymakers to keep inflation low by limiting the ability of the Central Bank to respond to adverse supply shocks. This restriction may be the main factor causing Japan's economic stagnation during the 1990 deflation [18]. Third, inflation 
serves as a lubricant making the nominal price of wages more flexible [21]. Studies show that prices and wages are more rigid in the downward direction than in the upward motion [31].

[6] makes the argument of "company-specific assets" to support the role of exchange rate movements in affecting foreign direct investment. Suppose that foreign and domestic firms have the same opportunity to purchase companyspecific assets in the domestic market, but different opportunities to generate returns on these assets in overseas markets. In this case, currency movements can affect the relative valuation of different assets. While domestic and foreign companies pay in the same currency, the company's specific assets can generate profits in different currencies.

Nigeria: After the adoption of the 1986 structural adjustment program policy in 1986, the country shifted from a fixed or rigid exchange rate regime to a more flexible regime [5]. In practice, no exchange rate is a "clean or pure buoy," i.e., a situation in which the exchange rate is left entirely determined by the market forces of demand and supply but the prevailing system is a managed buoy wherein the monetary authorities intervene periodically in the foreign exchange market of a country to achieve some strategic objectives [23]. Monetary policy has always been viewed as a fundamental instrument for many years to achieve macroeconomic stability that is often seen as a prerequisite for achieving sustainable output growth.

The exchange rate policy has been identified as one of the endogenous factors that can affect a country's economic performance [16]. The exchange rate is the price of a single currency in relation to that of another country. This is the number of units of currency required to purchase a number of units of another currency. This is the price at which one currency is exchanged for another. It measures the economic value of a country, especially in terms of currencies of the most developed countries such as the US dollar, British pound sterling, German deutsche mark, Japanese yen, French franc, Italian lira, and Canadian dollar [3]. In Nigeria, the exchange rate management is done by the central bank of Indonesia.

\section{Problem Formulation}

Based on these problems, the formulation of the problem in this study is as follows:

1. Do wages affect the regional investment policy on the manpower of Sidoarjo City?

2. Does inflation affect the investment policy area of the Region on Labor of Sidoarjo City?

3. Does the exchange rate have an effect on the investment policy of the regional investment area in manpower of Sidoarjo City?

\section{Conceptual and Hypothesis Framework}

\section{Conceptual Framework}

In order for this research to be more directed with the formulation of problems and goals to be achieved, it can be described as follows: 


\section{Hypothesis}

The hypothesis of this research is as follows:

1. There is an influence of wages on regional investment on manpower of Sidoarjo City.

2. There is an inflationary effect on regional investment on the manpower of Sidoarjo City.

3. There is an influence of the exchange rate with local investment on labor of Sidoarjo City.

\section{Method of Research}

\section{Population}

In this study, the population taken is the entire workforce whose data comes from the Central Bureau of Statistics in Sidoarjo which amounted to 64,792 workers in 2011 [4].

\section{Sample}

According to [4], the sample is part of the number and characteristics possessed by the population with certain criteria.

Determination of the number of samples using the Slovin formula is as follows:

$$
n=\frac{N}{1+N e^{2}} n=\frac{64.792}{1+\begin{array}{c}
64.792(0.10)^{2} \\
\text { rounded to } 100
\end{array}}=\frac{64.792}{1+647.92}=\frac{64.792}{648.92}=99.84
$$

Information:

$n \quad$ Sample size

$N$ Large population

$e \quad$ Desired level of trust/precision with a $10 \%$ confidence level

(See Appendix 4)

\section{Data Analysis Technique}

Data analysis technique is done by analyzing directly by understanding the existing data; the analysis is also done by using the computer assistance program SPSS 20.0.

\section{Testing of Research Instruments}

Validity Test Instrument validity is related to the suitability and accuracy of the function of the measuring instrument used. Therefore, before the instrument is used 
in the field, there is a need to test its validity. To test the validity, product moment correlation technique is processed using SPSS.

The validity test is obtained by correlating each score of the indicator variable; then the result is compared with the critical value at a significant level of 0.05 . If the results obtained are smaller than $r$-table, then the items that exist in the questionnaire do not show the value of the validity and so cannot be continued as a research instrument (see Appendix 1, point A).

Reliability Test Reliability concerns the accuracy of measuring tools. This accuracy can be assessed by statistical analysis to determine the measurement error. The analysis used in testing instrument reliability is done by using the alpha Cronbach formula which is processed using SPSS. The measurement item is said to be reliable if it has an alpha coefficient value greater than 0.6. Because according to Maholtra (2005: 310), a value of 0.6 or less generally indicates an unsatisfactory internal consistency reliability (see Appendix 1, point B).

\section{Classic Assumption Test}

\section{Normality Test}

Normality test is performed to test, in a regression model, independent and dependent variables or whether both have a normal distribution or not. The best model is the normal or near-normal distribution of data. Data normality can be detected by looking at the shape of the histogram curve with a balanced slope to the left and to the right and shaped like a bell or by looking at the dotted data points around the diagonal line and following the diagonal line from the normal P-Plot image [25] (see Appendix 2, point A).

\section{Multicollinearity Test}

This is used to test whether in a regression model a correlation is found between independent variables. If there is a correlation, then it is said there is a multicollinearity problem. In a good regression model, correlation between independent variables should not occur. Testing for presence or absence of multicollinearity is done by the variance inflation factor (VIF) method with the following provisions:

A. If $\mathrm{VIF}>10$, there is a multicollinearity problem.

B. If $\mathrm{VIF}<10$, there is no multicollinearity problem.

(See Appendix 2, point B)

\section{Autocorrelation Test}

This aims to test whether in a linear regression model there is a correlation between the confounding error in period $t$ and the intruder error in period $t-1$ [28]. If the 
regression model is good, there is no autocorrelation in the regression model, then the value of the Durbin Watson test is tested. According to [28], it has to be decided whether or not there is autocorrelation:

A. DW value $<1.10$ : there is autocorrelation.

B. DW value between 1.10 and 1.54: without conclusion.

C. DW value between 1.55 and 2.46: no autocorrelation.

D. DW value between 2.46 and 2.90: without conclusion.

E. DW value $>2.90$ : there is autocorrelation.

(See Appendix 2, point C)

\section{Heteroscedasticity Test}

Heteroscedasticity is a confounding variable which has a different variant from one observation to another or whose variants between independent variables are not the same; it violates the assumption of homoscedasticity, i.e., each explanatory variable has the same (constant) variant. A heteroscedasticity test can be done by a Glejser test, that is, by seeing the value of significance above level $=5 \%$, so it can be concluded that the regression model does not contain the existence of heterokedastisitas [13].

(See Appendix 2, point D)

\section{Data Analysis Using Multiple Liner Regression}

Multiple linear regression is used to test the fourth hypothesis, namely to find the effect of wages, inflation, and exchange rate on local investment policy. This analysis is used to find the functional relationship of all predictors with the criteria as well as to determine the contribution of predictor variables to the criteria, both relative donations and effective contributions.

Multiple linear regression is used to determine the effect of independent variables with dependent variable, wage, inflation, and exchange rate on the BPS investment policy of Sidoarjo. The regression model used is

$$
Y=a+b_{1} X_{1}+B_{2} X_{2}+b_{3} X_{3}+e
$$

Information:

$Y \quad$ Investment

a Price constants (price $Y$ when $X=0$ )

$b_{1} \quad$ Regression coefficient of the wage variable

$B_{2}$ Regression coefficient of inflation variables

$b_{3} \quad$ Regression coefficient of the exchange rate variable

$X_{1} \quad$ First independent variable (wages)

$X_{2} \quad$ Second independent variable (inflation)

$X_{3} \quad$ Third independent variable (exchange rate)

e Standard error

(See Appendix 3) 


\section{Hypothesis Testing}

\section{Testing of Partial Effect Hypothesis (T Test)}

The $t$ test is also called a test of individual significance. This $t$ test shows how far is the influence of independent variables partially to the dependent variable [13]. In formulating statistical hypotheses, the following are the rules of decision:

A. If the value of $t$ arithmetic $>t$ table, then Ho is accepted.

B. If the value of $t$ arithmetic $<t$ table, then Ho is rejected.

The rules of decision-making and $t$ test using SPSS are as follows:

1. If probability $>0.05$, then $\mathrm{Ho}$ is accepted and $\mathrm{Ha}$ is rejected.

2. If probability $<0.05$, then $\mathrm{Ho}$ is rejected and $\mathrm{Ha}$ is accepted.

\section{Data Analysis and Discussion of Research Results}

\section{Test Validity}

A validity test is performed to know the level of validity or truth of the instrument. From Table 2, the validity test can be found after performing the calculation using SPSS version 20 program; the results show that all items of each statement have significant value $(\leq 0.05)$, so the whole item is declared valid.

Table 2 Validity test

\begin{tabular}{lllll}
\hline Variable & & Correlation & Sig. & Note \\
\hline Wages $\left(X_{1}\right)$ & $X_{1.1}$ & $0.848^{* *}$ & 0.000 & Valid \\
& $X_{1.2}$ & $0.815^{* *}$ & 0.000 & Valid \\
& $X_{1.3}$ & $0.815^{* *}$ & 0.000 & Valid \\
& $X_{1.4}$ & $0.844^{* *}$ & 0.000 & Valid \\
Inflation $\left(X_{2}\right)$ & $X_{2.1}$ & $0.807^{* *}$ & 0.000 & Valid \\
& $X_{2.2}$ & $0.825^{* *}$ & 0.000 & Valid \\
& $X_{2.3}$ & $0.762^{* *}$ & 0.000 & Valid \\
Exchange rates $\left(X_{3}\right)$ & $X_{3.1}$ & $0.886^{* *}$ & 0.000 & Valid \\
& $X_{3.2}$ & $0.672^{* *}$ & 0.000 & Valid \\
Investment $(Y)$ & $X_{3.3}$ & $0.871^{* *}$ & 0.000 & Valid \\
& $Y_{1}$ & $0.894^{* *}$ & 0.000 & Valid \\
& $Y_{2}$ & $0.756^{* *}$ & 0.000 & Valid \\
& $Y_{3}$ & $0.873^{* *}$ & 0.000 & Valid \\
\hline
\end{tabular}

Source: SPSS Output Appendix Instrument Testing, data is processed 


\section{Reliability Test}

A questionnaire is said to be reliable if one's response to a statement is consistent or stable over time. The reliability test by using the alpha Cronbach technique said the instrument has a high reliable value if the value of the alpha Cronbach $>0.6$. From the analysis results obtained, the reliability coefficient is as follows:

In Table 3 are the obtained values of coefficient reliability Cronbach alpha on variable wages of 0.849 , variable inflation of 0.711 , exchange rate variable of 0.733 , and investment variable of 0.791 . Of all the variables, if the value of the reliability coefficient Cronbach alpha is more than 0.6 , it can be concluded that the instrument or questionnaire used is very reliable.

\section{Classic Assumption Test}

In order to obtain an unbiased and efficient estimator value of a multiple regression equation with the ordinary least square method, the implementation of data analysis must meet the following classical assumptions (Table 4):

\section{Normality Test}

A data normality test is used to test whether, in a regression model, the dependent variable, independent variable, or both have a normal distribution or not; from the test results obtained, the asymp.sig value for the wage variable is equal to 0.110 $(0.110>0.05)$; for the inflation variable, equal to $0.128(0.128>0.05)$; for the exchange rate variable, equal to $0.101(0.101>0.05)$; and for the investment variable, equal to $0.130(0.130>0.050)$. So, it can be concluded that all data is normally distributed.

\section{Multicollinearity Test}

A multicollinearity test is used to test whether the regression model found a correlation between independent variables (independent). From the test results obtained, the VIF value for the wage variable is $1.074(1.074<10)$; for the inflation variable, $1.140(1.140<10)$; and for the exchange rate variable, $1.088(1.088<10)$, so it can be said that the multiple linear regression used in this study is free from multicollinearity.

Table 3 Reliability coefficients

\begin{tabular}{llll}
\hline Variable & Alpha Cronbach value & Critical value & Note \\
\hline Wages & 0.849 & 0.6 & Reliable \\
Inflation & 0.711 & 0.6 & Reliable \\
Exchange rates & 0.733 & 0.6 & Reliable \\
Investment & 0.791 & 0.6 & Reliable \\
\hline
\end{tabular}

Source: SPSS Output Appendix Instrument Testing, data is processed 
Table 4 Classic assumption test results

\begin{tabular}{lll}
\hline Normality test & Result & Information \\
Wage & asymp.sig $=0.110(>0.05)$ & Normal \\
Inflation & asymp.sig $=0.128(>0.05)$ & Normal \\
Exchange rate & asymp.sig $=0.101(>0.05)$ & Normal \\
Investation & asymp.sig $=0.130(>0.05)$ & Normal \\
Multicollinearity test & Result & Information \\
Wage & $\mathrm{VIF}=1074(<10)$ & Free multicollinearity \\
Inflation & $\mathrm{VIF}=1140(<10)$ & Free multicollinearity \\
Exchange rate & $\mathrm{VIF}=1088(<10)$ & Free multicollinearity \\
Test Autocorrelation & $\mathrm{DW}=2275$ & Not affected by autocorrelation \\
Heteroscedasticity Test & Result & Information \\
Scatterplot is attached & There is no clear pattern, as well as & Not affected heteroscedasticity \\
& dots spread above and below the & \\
& zeros on the $Y$ axis & \\
\hline
\end{tabular}

\section{Heteroscedasticity Test}

The heteroscedasticity test was used to test whether in the regression model there was a variance inequality of the residual one observation to the other. In the scatterplot image below, the points appear to be spreading randomly, not forming a certain pattern clearly, and scattered either above or below the number 0 on the $Y$ axis. This means there is no heteroscedasticity in the regression model.

\section{Multiple Linear Regression Analysis and Hypothesis Testing}

From the result of multiple linear regression analysis, the amount of the constant and the regression coefficient for each variable are as follows:

From Table 5, the regression equation is

$$
Y=0.180+0.160 X_{1}+0.189 X_{2}+0.590 X_{3}+e
$$

Based on the equation, it can be explained as follows:

The constant value (a) is 0.180 .

It shows that if the wage free variable $\left(X_{1}\right)$, inflation $\left(X_{2}\right)$, and exchange rate $\left(X_{3}\right)$ are zero, the investment policy $(Y)$ will be 0.180 units. This means that without looking at wages $\left(X_{1}\right)$, inflation $\left(X_{2}\right)$, and the exchange rate $\left(X_{3}\right)$, then the predicted value of the investment policy $(Y)$ will be 0.180 units.

The results of this test support the new Keynesian and Keynesian models showing the positive impact of money on growth and employment levels that are different from the neutrality of money in new classic and classic models [9]. For policymakers, the empirical evidence contained in the time series as given in Figs. 1, 2, 3, 4, 5, and 6 is to test the theoretical basis while establishing fiscal, monetary, or exchange rate policies to stabilize output and employment by using interest rates, money supply, and value 
Table 5 Multiple linear regression analysis

\begin{tabular}{llllll}
\hline Variable & $\begin{array}{l}\text { Unstandardized } \\
\text { coefficients }(B)\end{array}$ & $\begin{array}{l}\text { Standardized } \\
\text { coefficients } \\
\text { beta }\end{array}$ & $t$ count & Sig. & Note \\
\hline Constant & 0.180 & & 0.110 & 0.913 & \\
Wages & 0.160 & 0.191 & 2371 & 0.020 & Significant \\
Inflation & 0.189 & 0.188 & 2262 & 0.026 & Significant \\
Exchange rates & 0.590 & 0.543 & 6692 & 0.000 & Significant \\
$R$ & & & & & $=0.647$ \\
$R^{2}$ & & & & & $=0.419$ \\
$F$ count & & & & & $=0.000$ \\
Sig. $F$ & & & & & \\
$\alpha$ & & & & & \\
Note: & & & & \\
-Total of data & & & & & \\
-Dependent variable & & & & & \\
\end{tabular}

Source: SPSS Output Appendix Multiple Linear Regression, data is processed

exchange as an instrument to achieve that goal [22]. Establishing the right relationship between stabilization goals and fiscal and monetary policy instruments is a major contribution to simultaneous macroeconometric equations modeling in the literature for this purpose $[11,12,14,15,30,33-35]$.

The value of the wage coefficient $\left(X_{1}\right)$ is 0.160 .

The regression coefficient marked positive indicates the wage influential direction to investment policy; if wage $\left(X_{1}\right)$ increases one unit, hence it will increase investment policy $(Y)$ equal to 0.160 units with assumption of inflation $\left(X_{2}\right)$ and exchange rate $\left(X_{3}\right)$ constant. This means that if the wage increases one unit, then the estimated value of investment policy increases by 0.160 units.

The results of this test support the empirical study conducted by [1, 2] which compares the average wage between domestic and foreign firms. They show that the average wage in foreign-owned plants tends to be about $30 \%$ higher than that for domestic plants. The second was done by [20] using plant-level datasets for Indonesia,

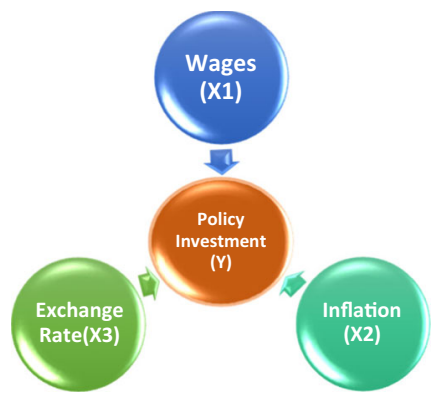

Source: Research variable is processed by author

Fig. 2 Concept framework. Source: Research variable is processed by author 


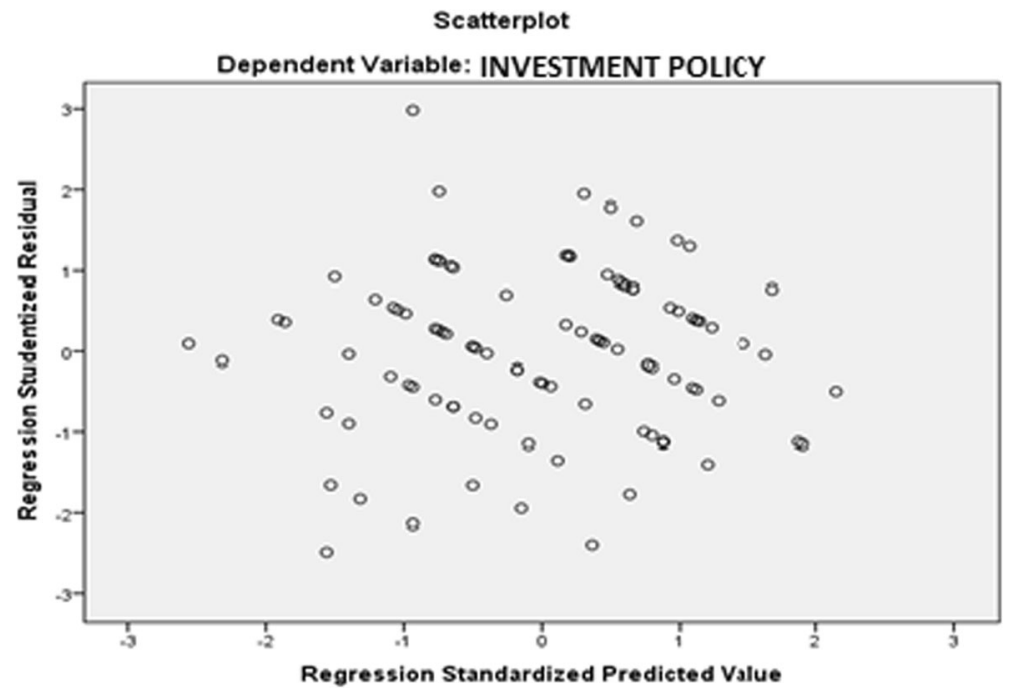

Fig. 3 Scatterplot. Dependent variable: investment policy

with detailed information on the composition of workers across the education category. They found that, while the average difference in labor quality is an important part of the raw crude wage premium, it remains substantial. Wages in foreign-owned plants are $12 \%$ higher for production workers and $20 \%$ for non-production workers. Reference [32] presents similar findings for five sub-Saharan African countries.

The value of the exchange rate coefficient $\left(X_{1}\right)$ is 0.590 .

The positive regression coefficient indicates that the exchange rate influences the investment policy, if the exchange rate $\left(X_{3}\right)$ increases one unit; it can increase the investment policy $(Y)$ of 0.590 units with the assumption of inflation $\left(X_{2}\right)$ and wage $\left(X_{1}\right)$ constant. This means that if the exchange rate increases one unit, then the estimated value of the investment policy increased by 0.300 units.

The results of this test support the previous review; the exchange rate policy has been identified as one of the endogenous factors that can affect the economic performance of a country [16]. The exchange rate is the price of a single currency in relation to that of another country. This is the number of units of currency required that can purchase a number of other units of currency. This is the price at which one currency is exchanged with another. It measures the economic value of a country, especially in terms of currencies of the most developed countries such as the US dollar, British pound sterling, German deutsche mark, Japanese yen, French franc, Italian lira, and Canadian dollar [3]. In Nigeria, the exchange rate management is done by the central bank of Indonesia.

The correlation coefficient $(R)$ illustrates the magnitude of the relationship between wage variables $\left(X_{1}\right)$, inflation $\left(X_{2}\right)$, and exchange rate $\left(X_{3}\right)$ and investment $(Y)$. Interpretation of the relationship between the variables $X$ and $Y$ can be seen from the correlation coefficient interpretation table in Sugiyono (2010: 319) as follows:

Table 6 shows the value of correlation coefficient $(R)$ of 0.647 . And the value if seen in Table 5 shows the level of strong relationship. It means that there is a strong relationship between wages $\left(X_{1}\right)$, inflation $\left(X_{2}\right)$, and exchange rate $\left(X_{3}\right)$ on investment policy $(Y)$. 
Table 6 Correlation coefficients interpretation

\begin{tabular}{ll}
\hline Interval correlation coefficient & Level of relationship \\
\hline $0.00-0,199$ & Very low \\
$0.20-0,399$ & Low \\
$0.40-0,599$ & Medium \\
$0.60-0,799$ & Strong \\
$0.80-1000$ & Very strong \\
\hline
\end{tabular}

The results of this test support the previous review by [6] to make the argument "special assets of the company" to support the role of exchange rate movements in affecting foreign direct investment. Suppose that foreign and domestic firms have the same opportunity to purchase company-specific assets in the domestic market, but different opportunities to generate returns on these assets in overseas markets. In this case, currency movements can affect the relative valuations of different assets. While domestic and foreign companies pay in the same currency, the company's specific assets can generate profits in different currencies.

The coefficient of determination $\left(R^{2}\right)$ is 0.419 .

This figure indicates that wages $\left(X_{1}\right)$, inflation $\left(X_{2}\right)$, and the exchange rate $\left(X_{3}\right)$ give variation or are able to contribute to an investment policy variable of $41.9 \%$, while the rest of the $58.1 \%$ is caused by other variables not included in research.

The results of this test support previous studies conducted by [17]; in this study, it was mentioned that imported affiliate technology increases with the host country's investment in the country and the level of education. Therefore, productivity benefits may rely heavily on the investment sector, technological gaps in certain investments, and host country environments. However, [29] claim that emphasized monetary factors at the expense of supply factors in Ghana and concluded that supply constraints are the main force behind inflation.

\section{Conclusions and Suggestions}

\section{Conclusion}

Based on the results of data analysis using multiple linear regressions with the help of SPSS program version 20 and the discussion that has been done, and then the conclusion of the study "Influence wages, inflation and exchange rate of investment area on labor in Sidoarjo city" and referring to research objectives, hypotheses, and analytical models, the conclusions of this study are as follows:

1. There is an effect of wages on regional investment on the workforce of Sidoarjo City; this is evidenced by the $t$ test, which obtained a $t$-count wage variable of 2.371 with a significance value of $0.020(0.020<0.05)$.

2. Characteristic influence of inflation on regional investment on labor in Sidoarjo City; this is proved by the $t$ test, which obtained a $t$-count inflation variable equal to 2.262 with a significance value equal to $0.026(0.026<0.05)$. 
3. There is an exchange rate effect on local investment on the workforce of Sidoarjo City; this is proved by the $t$ test, which obtained a $t$-count exchange rate variable equal to 6.692 with a significance value equal to $0.000(0.000<0.05)$.

\section{Suggestions}

Based on the results of research and conclusions that have been taken, related suggestions that can be asked are as follows:

1. It is expected that the workforce in the city of Sidoarjo can set aside some of the wages they receive for investment needs, whether in the form of land, house, or gold. By way of setting aside some of the wages they receive, it is expected that the wages they receive are not exhausted only for consumption needs.

2. It is expected that the workforce in the city of Sidoarjo, in order to manage finances, minimize spending at the time of higher inflation. Because of the impact of inflation, the price of goods will be higher. This will affect the amount of money to be invested.

3. It is expected that the workforce in the city of Sidoarjo, if shopping or buying goods, choose goods that use IDR (Indonesian rupiah) instead of a foreign currency, because if the goods use the price of the foreign currency, then the price of the goods will tend to rise and fall, so it will affect the amount of money which we will invest.

\section{Highlights}

\section{Findings}

Based on the results of calculations and tests conducted, it can be explained that there is an effect of wages on regional investment of labor followed by the characteristics of inflation on labor that affects the exchange rate of investment.

This illustrates for policymakers, which empirical evidence exists in a series of time to test the theoretical basis while establishing fiscal, monetary, or exchange rate policies to stabilize output and employment by using interest rates, money supply, and exchange rates as instruments for achieving goals.

\section{Implications}

The findings of the previous research and theories presented above have implications for policymakers, to establish fiscal, monetary or exchange rate policies in stabilizing interest rates, money supply and exchange rates in Sidoarjo regency.

\section{Practical Implications}

After conducting policy-maker research, it can apply empirical evidence in the time series to test the theoretical basis while establishing fiscal, monetary, or exchange-rate 
policies to stabilize output and employment by using interest rates, money supply, and exchange rates.

\section{Social Implications}

From the results of policy-makers' research, it can apply the empirical evidence in the time series as the theoretical basis while establishing fiscal, monetary, or exchange rate policies to stabilize output and employment by using interest rates, money supply, and exchange rates in other cities.

\section{Originality/Value}

From the design of this study, the originality or value of research is that wages, inflation, and exchange rates affect the investment policy. As the theoretical basis of policy makers can implement fiscal, monetary, or exchange rate policy to stabilize output and employment by using interest rates, the amount of money outstanding and exchange rate are its instrument.

\section{Appendix 1. Test Research Instruments}

\section{Validity Tests}

Wage Variables $\left(X_{1}\right)$

Correlations

\begin{tabular}{lllllll}
\hline & & $X_{1.1}$ & $X_{1.2}$ & $X_{1.3}$ & $X_{1.4}$ & $X_{1 \cdot \text { TOTAL }}$ \\
\hline$X_{1.1}$ & Pearson correlation & 1 & $0.507^{* * *}$ & $0.824^{* * *}$ & $0.463^{* * *}$ & $0.848^{* * *}$ \\
& Sig. (2-tailed) & & 0.000 & 0.000 & 0.000 & 0.000 \\
& $N$ & 100 & 100 & 100 & 100 & 100 \\
$X_{1.2}$ & Pearson correlation & $0.507^{* * *}$ & 1 & $0.361^{* *}$ & $0.846^{* *}$ & $0.815^{* *}$ \\
& Sig. (2-tailed) & 0.000 & & 0.000 & 0.000 & 0.000 \\
& $N$ & 100 & 100 & 100 & 100 & 100 \\
$X_{1.3}$ & Pearson correlation & $0.824^{* *}$ & $0.361^{* * *}$ & 1 & $0.515^{* *}$ & $0.815^{* *}$ \\
& Sig. (2-tailed) & 0.000 & 0.000 & & 0.000 & 0.000 \\
& $N$ & 100 & 100 & 100 & 100 & 100 \\
$X_{1.4}$ & Pearson correlation & $0.463^{* *}$ & $0.846^{* *}$ & $0.515^{* *}$ & 1 & $0.844^{* *}$ \\
& Sig. (2-tailed) & 0.000 & 0.000 & 0.000 & & 0.000 \\
& $N$ & 100 & 100 & 100 & 100 & 100 \\
$X_{1 . \text { TOTAL }}$ & Pearson correlation & $0.848^{* *}$ & $0.815^{* * *}$ & $0.815^{* * *}$ & $0.844^{* * *}$ & 1 \\
& Sig. (2-tailed) & 0.000 & 0.000 & 0.000 & 0.000 & \\
& $N$ & 100 & 100 & 100 & 100 & 100 \\
\hline
\end{tabular}

$* *$ Correlation is significant at the 0.01 level (2-tailed) 


\section{Inflation Variables $\left(X_{2}\right)$}

Correlations

\begin{tabular}{llllll}
\hline & & $X_{2.1}$ & $X_{2.2}$ & $X_{2.3}$ & $X_{2 . \text { TOTAL }}$ \\
\hline$X_{2.1}$ & Pearson correlation & 1 & $0.579^{* *}$ & $0.376^{* * *}$ & $0.807^{* * *}$ \\
& Sig. (2-tailed) & & 0.000 & 0.000 & 0.000 \\
& $N$ & 100 & 100 & 100 & 100 \\
$X_{2.2}$ & Pearson correlation & $0.579^{* * *}$ & 1 & $0.411^{* *}$ & $0.825^{* *}$ \\
& Sig. (2-tailed) & 0.000 & & 0.000 & 0.000 \\
& $N$ & 100 & 100 & 100 & 100 \\
$X_{2.3}$ & Pearson correlation & $0.376^{* *}$ & $0.411^{* *}$ & 1 & $0.762^{* *}$ \\
& Sig. (2-tailed) & 0.000 & 0.000 & & 0.000 \\
& $N$ & 100 & 100 & 100 & 100 \\
$X_{2 . \text { TOTAL }}$ & Pearson correlation & $0.807^{* *}$ & $0.825^{* *}$ & $0.762^{* *}$ & 1 \\
& Sig. (2-tailed) & 0.000 & 0.000 & 0.000 & 100 \\
\hline & $N$ & 100 & 100 & 100 & 1 \\
\hline
\end{tabular}

** Correlation is significant at the 0.01 level (2-tailed)

Exchange Rate Variables $\left(X_{3}\right)$

Correlations

\begin{tabular}{llllll}
\hline & & $X_{3.1}$ & $X_{3.2}$ & $X_{3.3}$ & $X_{3 . \text { TOTAL }}$ \\
\hline$X_{3.1}$ & Pearson correlation & 1 & $0.318^{* * *}$ & $0.852^{* * *}$ & $0.886^{* *}$ \\
& Sig. (2-tailed) & & 0.001 & 0.000 & 0.000 \\
& $N$ & 100 & 100 & 100 & 100 \\
$X_{3.2}$ & Pearson correlation & $0.318^{* *}$ & 1 & $0.283^{* * *}$ & $0.672^{* * *}$ \\
& Sig. (2-tailed) & 0.001 & & 0.004 & 0.000 \\
& $N$ & 100 & 100 & 100 & 100 \\
$X_{3.3}$ & Pearson correlation & $0.852^{* *}$ & $0.283^{* * *}$ & 1 & $0.871^{* *}$ \\
& Sig. (2-tailed) & 0.000 & 0.004 & & 0.000 \\
& $N$ & 100 & 100 & 100 & 100 \\
$X_{3 . \text { TOTAL }}$ & Pearson correlation & $0.886^{* * *}$ & $0.672^{* * *}$ & $0.871^{* * *}$ & 1 \\
& Sig. (2-tailed) & 0.000 & 0.000 & 0.000 & \\
& $N$ & 100 & 100 & 100 & 100 \\
\hline
\end{tabular}

**Correlation is significant at the 0.01 level (2-tailed) 


\section{Investment Policy Variable $(Y)$}

Correlations

\begin{tabular}{llllll}
\hline & & $Y_{1}$ & $Y_{2}$ & $Y_{3}$ & $Y_{\text {TOTAL }}$ \\
\hline$Y_{1}$ & Pearson correlation & 1 & $0.472^{* *}$ & $0.792^{* *}$ & $0.894^{* *}$ \\
& Sig. (2-tailed) & & 0.000 & 0.000 & 0.000 \\
$Y_{2}$ & $N$ & 100 & 100 & 100 & 100 \\
& Pearson correlation & $0.472^{* *}$ & 1 & $0.419^{* *}$ & $0.756^{* *}$ \\
& Sig. (2-tailed) & 0.000 & & 0.000 & 0.000 \\
$Y_{3}$ & $N$ & 100 & 100 & 100 & 100 \\
& Pearson correlation & $0.792^{* *}$ & $0.419^{* *}$ & 1 & $0.873^{* *}$ \\
& Sig. (2-tailed) & 0.000 & 0.000 & & 0.000 \\
$Y_{\text {TOTAL }}$ & $N$ & 100 & 100 & 100 & 100 \\
& Pearson correlation & 0.894 & 0.756 & 0.873 & 1 \\
& Sig. (2-tailed) & 0.000 & 0.000 & 0.000 & 100 \\
\hline
\end{tabular}

$* *$ Correlation is significant at the 0.01 level (2-tailed)

\section{Reliability Tests}

Wage Variables $\left(X_{1}\right)$

Case Processing Summary

\begin{tabular}{llll}
\hline & & $N$ & $\%$ \\
\hline Cases & Valid & 100 & 100.0 \\
& Excluded $^{\mathrm{a}}$ & 0 & 0.0 \\
& Total & 100 & 100.0 \\
\hline
\end{tabular}

${ }^{\mathrm{a}}$ Listwise deletion based on all variables in the procedure

\section{Reliability Statistics}

\begin{tabular}{lc} 
Cronbach's alpha & $N$ of items \\
\hline 0.849 & 4
\end{tabular}

\section{Inflation Variables $\left(X_{2}\right)$}

Case Processing Summary

\begin{tabular}{llll}
\hline & & $N$ & $\%$ \\
\hline Cases & Valid & 100 & 100.0 \\
& Excluded $^{\mathrm{a}}$ & 0 & 0.0 \\
& Total & 100 & 100.0 \\
\hline
\end{tabular}

\footnotetext{
${ }^{\mathrm{a}}$ Listwise deletion based on all variables in the procedure
} 


\section{Reliability Statistics}

\begin{tabular}{lc}
\hline Cronbach's alpha & $N$ of items \\
\hline 0.711 & 3 \\
\hline
\end{tabular}

Exchange Rate Variables $\left(X_{3}\right)$

Case Processing Summary

\begin{tabular}{llll}
\hline & & $N$ & $\%$ \\
\hline Cases & Valid & 100 & 100.0 \\
& Excluded $^{\mathrm{a}}$ & 0 & 0.0 \\
& Total & 100 & 100.0 \\
\hline
\end{tabular}

${ }^{\mathrm{a}}$ Listwise deletion based on all variables in the procedure

\section{Reliability Statistics}

\begin{tabular}{lc}
\hline Cronbach's alpha & $N$ of items \\
\hline 0.733 & 3 \\
\hline
\end{tabular}

Investment Policy Variable $(Y)$

Case Processing Summary

\begin{tabular}{llll}
\hline & & $N$ & $\%$ \\
\hline Cases & Valid & 100 & 100.0 \\
& Excluded & 0.0 \\
& Total & 0 & 100.0 \\
\hline
\end{tabular}

${ }^{\mathrm{a}}$ Listwise deletion based on all variables in the procedure

\section{Reliability Statistics}

\begin{tabular}{lc}
\hline Cronbach's alpha & $N$ of Items \\
\hline 0.791 & 3 \\
\hline
\end{tabular}




\section{Appendix 2. Test of Classical Assumptions}

\section{Normality Test}

One-Sample Kolmogorov-Smirnov Test

\begin{tabular}{|c|c|c|c|c|c|}
\hline & & Wage & Inflation & Exchange rate & Investment policy \\
\hline$N$ & & 100 & 100 & 100 & 100 \\
\hline \multirow[t]{2}{*}{ Normal parameters ${ }^{\mathrm{a}, \mathrm{b}}$} & Mean & 17.1400 & 12.2600 & 12.1800 & 12.4300 \\
\hline & Std. deviation & 1.83138 & 1.52169 & 1.40978 & 1.53251 \\
\hline \multirow[t]{3}{*}{ Most extreme differences } & Absolute & 0.120 & 0.146 & 0.200 & 0.145 \\
\hline & Positive & 0.120 & 0.146 & 0.120 & 0.110 \\
\hline & Negative & -0.095 & -0.137 & -0.200 & -0.145 \\
\hline Kolmogorov-Smirnov $Z$ & & 1205 & 1462 & 1996 & 1450 \\
\hline Asymp. Sig. (2-tailed) & & 0.110 & 0.128 & 0.101 & 0.130 \\
\hline
\end{tabular}

${ }^{\mathrm{a}}$ Test distribution is normal

${ }^{\mathrm{b}}$ Calculated from data

\section{Multicollinearity Test}

\section{Coefficients}

\begin{tabular}{|c|c|c|c|c|c|c|c|c|}
\hline \multicolumn{2}{|c|}{ Model } & \multicolumn{2}{|c|}{$\begin{array}{l}\text { Unstandardized } \\
\text { coefficients }\end{array}$} & \multirow{2}{*}{$\begin{array}{l}\text { Standardized } \\
\text { coefficients }\end{array}$} & \multirow[t]{2}{*}{$t$} & \multirow[t]{2}{*}{ Sig. } & \multicolumn{2}{|c|}{$\begin{array}{l}\text { Collinearity } \\
\text { statistics }\end{array}$} \\
\hline$B$ & Std. error & Beta & Tolerance & & & & & \\
\hline \multirow[t]{4}{*}{1} & (Constant) & 0.180 & 1640 & & 0.110 & 0.913 & & \\
\hline & Wage & 0.160 & 0.067 & 0.191 & 2371 & 0.020 & 0.931 & 1074 \\
\hline & Inflation & 0.189 & 0.084 & 0.188 & 2262 & 0.026 & 0.877 & 1140 \\
\hline & Exchange rate & 0.590 & 0.088 & 0.543 & 6692 & 0.000 & 0.919 & 1088 \\
\hline
\end{tabular}

Dependent variable: investment policy

\section{Autocorrelation Test}

Model Summary

\begin{tabular}{llllll}
\hline Model & $R$ & $R^{2}$ & Adjusted $R^{2}$ & Std. error of the estimate & Durbin-Watson \\
\hline 1 & $0.647^{\mathrm{a}}$ & 0.419 & 0.401 & 1.18618 & 2275 \\
\hline
\end{tabular}

Dependent variable: investment policy

a Predictors: (constant), exchange rate, wage, inflation 


\section{Heteroscedasticity Test}

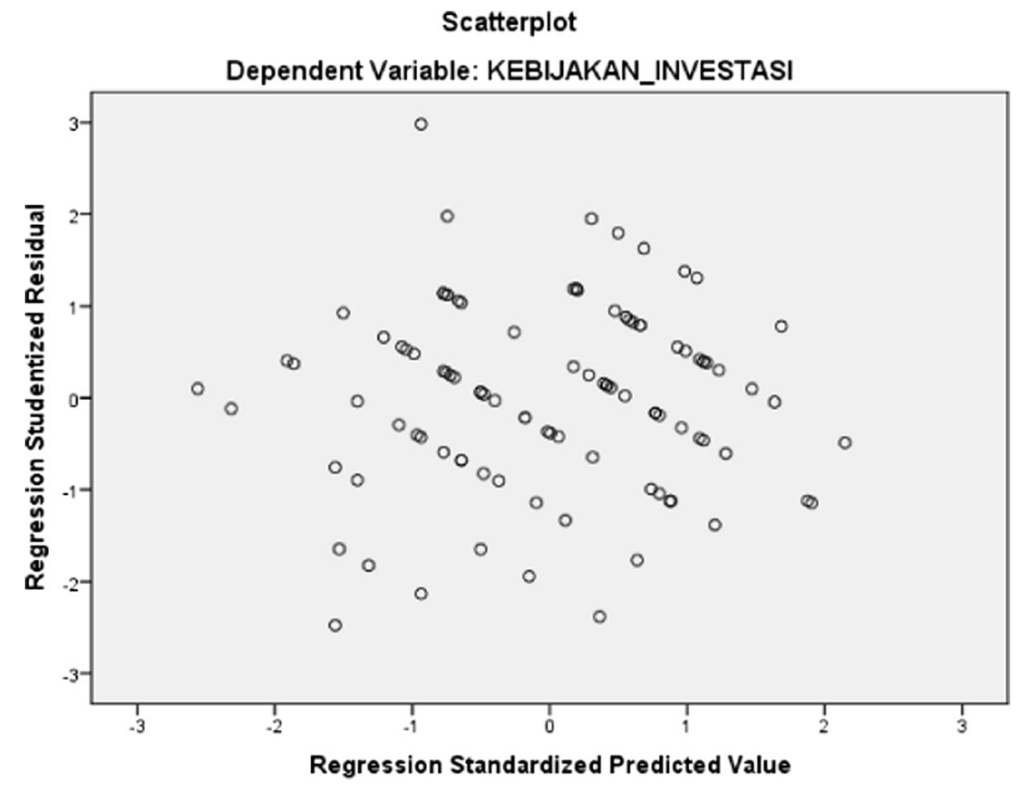

\section{Appendix 3. Test of Regression Linear Multiple}

Model Summary

\begin{tabular}{llllll}
\hline Model & $R$ & $R^{2}$ & Adjusted $R^{2}$ & Std. error of the estimate & Durbin-Watson \\
\hline 1 & $0.647^{\mathrm{a}}$ & 0.419 & 0.401 & 1.18618 & 2275 \\
\hline
\end{tabular}

Dependent variable: investment policy

a Predictors: (constant), exchange rate, wage, inflation

ANOVA

\begin{tabular}{lllllll}
\hline Model & & Sum of squares & df & Mean square & $F$ & Sig. \\
\hline 1 & Regression & 97.435 & 3 & 32.478 & 23.083 & $0.000^{\mathrm{a}}$ \\
& Residual & 135.075 & 96 & 1407 & & \\
& Total & 232.510 & 99 & & & \\
\hline
\end{tabular}

Dependent variable: investment policy

a Predictors: (constant), exchange rate, wage, inflation 


\section{Coefficients}

\begin{tabular}{|c|c|c|c|c|c|c|c|c|}
\hline \multicolumn{2}{|c|}{ Model } & \multicolumn{2}{|c|}{$\begin{array}{l}\text { Unstandardized } \\
\text { coefficients }\end{array}$} & \multirow{2}{*}{$\begin{array}{l}\begin{array}{l}\text { Standardized } \\
\text { coefficients }\end{array} \\
\text { VIF }\end{array}$} & \multirow[t]{2}{*}{$t$} & \multirow[t]{2}{*}{ Sig. } & \multicolumn{2}{|c|}{ Collinearity statistics } \\
\hline$B$ & Std. error & Beta & Tolerance & & & & & \\
\hline \multirow[t]{4}{*}{1} & (Constant) & 0.180 & 1640 & & 0.110 & 0.913 & & \\
\hline & Upah & 0.160 & 0.067 & 0.191 & 2371 & 0.020 & 0.931 & 1074 \\
\hline & Inflasi & 0.189 & 0.084 & 0.188 & 2262 & 0.026 & 0.877 & 1140 \\
\hline & Nilai_Tukar & 0.590 & 0.088 & 0.543 & 6692 & 0.000 & 0.919 & 1088 \\
\hline
\end{tabular}

Dependent variable: investment policy

\section{Charts}

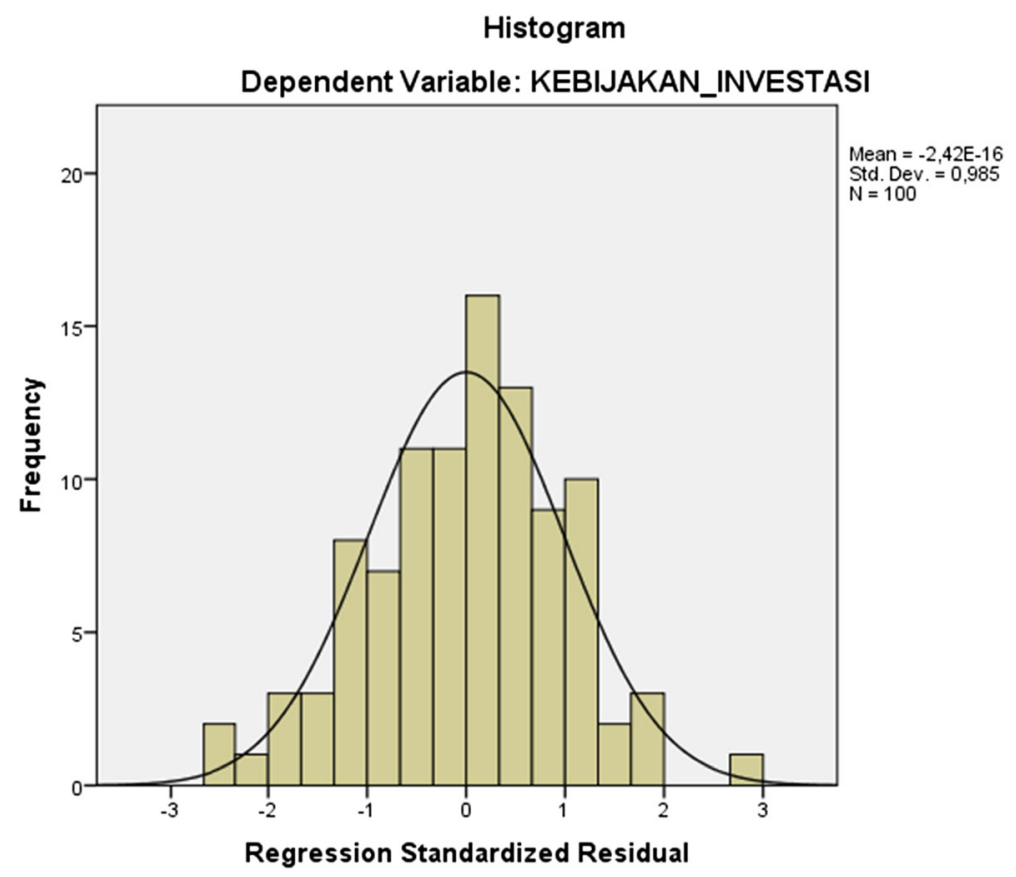




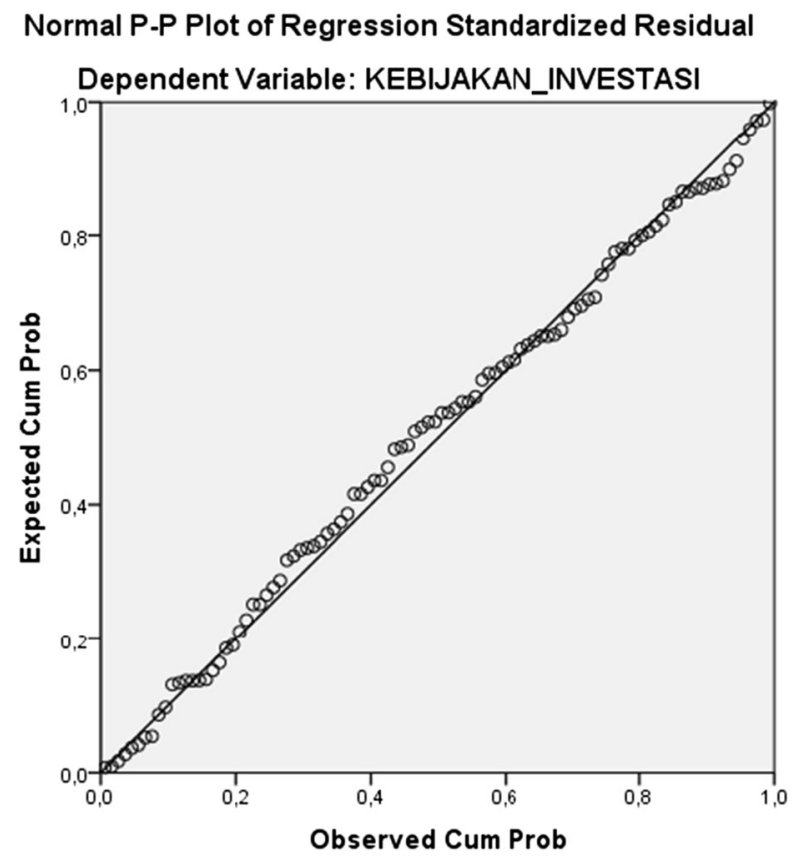

Scatterplot

Dependent Variable: KEBIJAKAN_INVESTASI

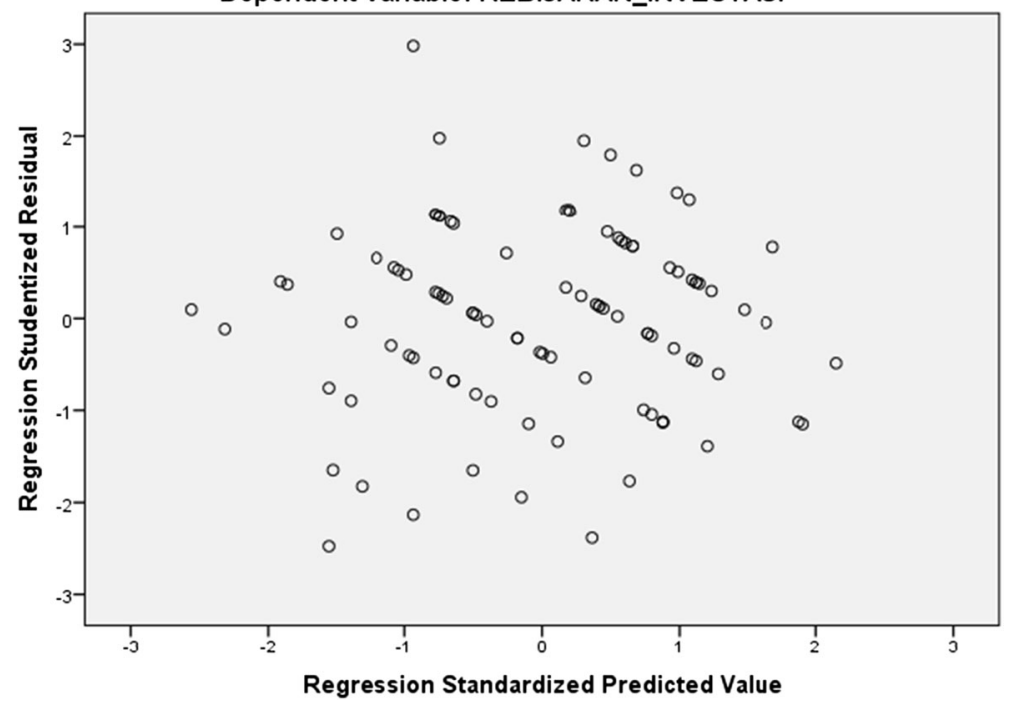




\section{Appendix 4. Table of Respondent's Response Frequency}

\section{Wage variables $\left(X_{1}\right)$}

\begin{tabular}{|c|c|c|c|c|c|}
\hline & & Frequency & Percent & Valid percent & Cumulative percent \\
\hline \multicolumn{6}{|l|}{$X_{1.1}$} \\
\hline \multirow[t]{4}{*}{ Valid } & 3.00 & 21 & 21.0 & 21.0 & 21.0 \\
\hline & 4.00 & 46 & 46.0 & 46.0 & 67.0 \\
\hline & 5.00 & 33 & 33.0 & 33.0 & 100.0 \\
\hline & Total & 100 & 100.0 & 100.0 & \\
\hline \multicolumn{6}{|l|}{$X_{1.2}$} \\
\hline \multirow[t]{4}{*}{ Valid } & 3.00 & 15 & 15.0 & 15.0 & 15.0 \\
\hline & 4.00 & 38 & 38.0 & 38.0 & 53.0 \\
\hline & 5.00 & 47 & 47.0 & 47.0 & 100.0 \\
\hline & Total & 100 & 100.0 & 100.0 & \\
\hline \multicolumn{6}{|l|}{$X_{1.3}$} \\
\hline \multirow[t]{5}{*}{ Valid } & 2.00 & 1 & 1.0 & 1.0 & 1.0 \\
\hline & 3.00 & 14 & 14.0 & 14.0 & 15.0 \\
\hline & 4.00 & 37 & 37.0 & 37.0 & 52.0 \\
\hline & 5.00 & 48 & 48.0 & 48.0 & 100.0 \\
\hline & Total & 100 & 100.0 & 100.0 & \\
\hline \multicolumn{6}{|l|}{$X_{1.4}$} \\
\hline \multirow[t]{4}{*}{ Valid } & 3.00 & 6 & 6.0 & 6.0 & 6.0 \\
\hline & 4.00 & 50 & 50.0 & 50.0 & 56.0 \\
\hline & 5.00 & 44 & 44.0 & 44.0 & 100.0 \\
\hline & Total & 100 & 100.0 & 100.0 & \\
\hline
\end{tabular}

Inflation Variables $\left(X_{2}\right)$

\begin{tabular}{|c|c|c|c|c|c|}
\hline & & Frequency & Percent & Valid percent & Cumulative percent \\
\hline \multicolumn{6}{|l|}{$X_{2.1}$} \\
\hline \multirow[t]{4}{*}{ Valid } & 3.00 & 21 & 21.0 & 21.0 & 21.0 \\
\hline & 4.00 & 50 & 50.0 & 50.0 & 71.0 \\
\hline & 5.00 & 29 & 29.0 & 29.0 & 100.0 \\
\hline & Total & 100 & 100.0 & 100.0 & \\
\hline \multicolumn{6}{|l|}{$X_{2.2}$} \\
\hline \multirow[t]{4}{*}{ Valid } & 3.00 & 19 & 19.0 & 19.0 & 19.0 \\
\hline & 4.00 & 56 & 56.0 & 56.0 & 75.0 \\
\hline & 5.00 & 25 & 25.0 & 25.0 & 100.0 \\
\hline & Total & 100 & 100.0 & 100.0 & \\
\hline
\end{tabular}




\begin{tabular}{|c|c|c|c|c|c|}
\hline & & Frequency & Percent & Valid percent & Cumulative percent \\
\hline \multicolumn{6}{|l|}{$X_{2.3}$} \\
\hline \multirow[t]{5}{*}{ Valid } & 2.00 & 3 & 3.0 & 3.0 & 3.0 \\
\hline & 3.00 & 16 & 16.0 & 16.0 & 19.0 \\
\hline & 4.00 & 47 & 47.0 & 47.0 & 66.0 \\
\hline & 5.00 & 34 & 34.0 & 34.0 & 100.0 \\
\hline & Total & 100 & 100.0 & 100.0 & \\
\hline
\end{tabular}

\section{Exchange Rate Variables $\left(X_{3}\right)$}

\begin{tabular}{lccccc}
\hline & & Frequency & Percent & Valid percent & Cumulative percent \\
\hline$X_{3.1}$ & & & & & \\
Valid & 3.00 & 18 & 18.0 & 18.0 & 18.0 \\
& 4.00 & 50 & 50.0 & 50.0 & 68.0 \\
& 5.00 & 32 & 32.0 & 32.0 & 100.0 \\
& Total & 100 & 100.0 & 100.0 & \\
$X_{3.2}$ & & & & & 7.0 \\
Valid & 2.00 & 7 & 7.0 & 7.0 & 27.0 \\
& 3.00 & 20 & 20.0 & 20.0 & 73.0 \\
& 4.00 & 46 & 46.0 & 46.0 & 100.0 \\
& 5.00 & 27 & 27.0 & 27.0 & 1.0 \\
& Total & 100 & 100.0 & 100.0 & 18.0 \\
Valid & & & & & 70.0 \\
& 2.00 & 1 & 1.0 & 1.0 & 100.0 \\
& 3.00 & 17 & 17.0 & 17.0 & \\
& 4.00 & 52 & 52.0 & 52.0 & \\
& 5.00 & 30 & 30.0 & 30.0 & \\
& Total & 100 & 100.0 & 100.0 & \\
\hline
\end{tabular}

Investment Policy Variable $(Y)$

\begin{tabular}{llllll}
\hline & & Frequency & Percent & Valid percent & Cumulative percent \\
\hline$Y_{1}$ & & & & & \\
Valid & 2.00 & 1 & 1.0 & 1.0 & 1.0 \\
& 3.00 & 16 & 16.0 & 16.0 & 17.0 \\
& 4.00 & 49 & 49.0 & 49.0 & 66.0 \\
& 5.00 & 34 & 34.0 & 34.0 & 100.0 \\
& Total & 100 & 100.0 & 100.0 &
\end{tabular}




\begin{tabular}{|c|c|c|c|c|c|}
\hline & & Frequency & Percent & Valid percent & Cumulative percent \\
\hline \multicolumn{6}{|l|}{$Y_{2}$} \\
\hline \multirow[t]{5}{*}{ Valid } & 2.00 & 1 & 1.0 & 1.0 & 1.0 \\
\hline & 3.00 & 16 & 16.0 & 16.0 & 17.0 \\
\hline & 4.00 & 50 & 50.0 & 50.0 & 67.0 \\
\hline & 5.00 & 33 & 33.0 & 33.0 & 100.0 \\
\hline & Total & 100 & 100.0 & 100.0 & \\
\hline \multicolumn{6}{|l|}{$Y_{3}$} \\
\hline \multirow[t]{5}{*}{ Valid } & 2.00 & 7 & 7.0 & 7.0 & 7.0 \\
\hline & 3.00 & 14 & 14.0 & 14.0 & 21.0 \\
\hline & 4.00 & 39 & 39.0 & 39.0 & 60.0 \\
\hline & 5.00 & 40 & 40.0 & 40.0 & 100.0 \\
\hline & Total & 100 & 100.0 & 100.0 & \\
\hline
\end{tabular}

Open Access This article is distributed under the terms of the Creative Commons Attribution 4.0 International License (http://creativecommons.org/licenses/by/4.0/), which permits unrestricted use, distribution, and reproduction in any medium, provided you give appropriate credit to the original author(s) and the source, provide a link to the Creative Commons license, and indicate if changes were made.

\section{References}

1. Aitken, B. J., \& Harrison, A. E. (1999). Do Domestic Firms Benefit from Direct Foreign Investment? Evidence from Venezuela. American Economic Review 89 (3): 605-618.

2. Aitken, B. J., Harrison, A. E., \& R. E. Lipsey (1996). Wages and Foreign Ownership: A Comparative Study of Mexico, Venezuela, and the United States.Journal of International Economics 40 (3): 345-371.

3. Akpokodje, G., Rao, N., Palmer-Jones, R., Akanji, B., Ajala, B., \& Papyrakis, E. (2009). Gender and Growth Assessment - Nigeria: National Overview. Report produced for the Department for International Development (DFID)/Canadian International Development Agency (CIDA) retrive from : https:/www. uea.ac.uk/documents/439774/1029130/gender-and-growth-assessment-microeconomic.pdf/05d8c07c5522-49f3-b1ab-d6dc585f152b

4. Arikunto, S., (1996). Statistik untuk penelitian. Jakarta: Rineka Cipta.

5. Azeez, B.A., Kolapo, F.T. \& Ajayi, L.B. (2012). Effect of Exchange Rate Volatility on macroeconomic performance in Nigeria. Interdisciplinary Journal of Contemporary Research in Business. (1): 149-155.

6. Blonigen, Bruce. (1997), "Firm-Specific Assets and the Link between Exchange Rates and Foreign Direct Investment." The American Economic Review, Vol. 87, No. 3, pp. 447465.

7. BPS Sidoarjo (2010). retrive from : https://sidoarjokab.bps.go.id/statictable/2017/08/01/57/lajupertumbuhan-pdrb-kabupaten-sidoarjo-menurut-pengeluaran-2010-2016.html

8. Ajay Chhibber and Nemat Shafik, (1990), "Exchange reform, parallel markets, and inflation in Africa : the case of Ghana," Policy Research Working Paper Series 427, The World Bank

9. Desai, M. \& Weber, G. (1988), A keynesian macro-econometric model of the UK: 1955-1984. J. Appl. Econ., 3: 1-33.

10. Driffill, J., \& Schultz, C. (1990). "Wage Setting And Stabilization Policy In A Game With Renegociation, " Papers 9003, Tilburg - Center for Economic Research.

11. Fair, R.C., \& TaylorJ .B. (1983). Solution and maximum likelihood estimation of dynamic nonlinear rational expectations models. Econometrica 51: 1169-1185.

12. Garratt, A., Lee, K., Hashem Pesaran, M. and Shin, Y. (2003), A Long run structural macroeconometric model of the UK*. The Economic Journal, 113: 412-455. 
13. Ghozali, I. (2006). Aplikasi Analisis Multivariate dengan Program SPSS. Edisi Kedua. Yogyakarta. Penerbit Universitas Diponegoro.

14. Holly, S., \& Weale, M. (2000). Econometric modelling: Techniques and applications. Cambridge, UK: Cambridge University Press.

15. Holly, S. \& Weale, M. (eds.) (2000). Economic forecasting in the face of structural breaks, in) Econometric Modelling: Techniques and Applications. Cambridge University Press. 3-37. With David F. Hendry.retrive from :https://core.ac.uk/download/pdf/7371067.pdf

16. Jameela, O.Y. (2010). Exchange Rate Changes and Output Performance in Nigeria: A Sectorial Analysis. Journal of Social Sciences. 7 (5): 380-387.

17. Kokko, A., \& Blomstrom, M. (1995). "Policies to Encourage Inflows of Technology through Foreign Multinationals." World Development 23 (3): 49568, https://doi.org/10.1016/0305-750X(94)00131.

18. Krugman, P. (1998). It's Baaack: Japan's Slump and the Return of the Liquidity Trap. Brookings Papers on Economic Activity, no. 2, 1372005. Retrive from : https://www.brookings.edu/wpcontent/uploads/1998 /06/1998b_bpea_krugman_dominquez_rogoff.pdf.

19. Lipsey, R. E. (2004). Home and Host Country Effects of FDI. In R. E. Baldwin and L. A. Winters (eds.), Challenges to Globalization. Chicago: University of Chicago Press.

20. Lipsey, R. E., \& F. Sjöholm (2004). Foreign Direct Investment, Education, and Wages in Indonesian Manufacturing. Journal of Development Economics 73 (1): 415-422.

21. Lucas, R.E.J (1990). Why Doesn't Capital Flow from Rich to Poor Countries? The American Economic Review, Vol. 80, No. 2, Papers and Proceedings of the Hundred and Second Annual Meeting of the American Economic Association. (May, 1990), pp. 92-96.

22. Mellis, C. \& Whittaker, R. (2000). Treasury's forecast of GDP and RPI: how have they changes and what are the uncertainties, Chapter 3 in Holly. In S. and Weale, M. (Eds.), Econometric modelling: Techniques and applications. Cambridge: Cambridge University Press.

23. Mordi, M. C. (2006). Challenges of exchange rate volatility in economic management in Nigeria. In S. A. Okogbue (Ed.), The dynamics of exchange rate in Nigeria (Vol. 30, pp. 17-25). Abuja: Central Bank of Nigeria Bullion.

24. Morrissey \& TeVelde (2003). Foreign Direct Investment and Income Inequality in Latin America, retrive from : https://www.odi.org/sites/odi.org.uk/files/odi-assets/publications-opinion-files/1928.pdf

25. Nugroho, A. (2005). Strategi Jitu Memilih Metode Statistic Penelitian Dengan SPSS, Andi Yogyakarta, Yogyakarta.

26. Priyono (2016). Esensi Ekonomi Makro, Zifatama publisher, Sidoarjo.

27. Romer, P. M. (1990). "Endogenous Technological Change". Journal of Political Economy, 98, S71S102.

28. Santoso, S. (2009). Mengatasi Masalah Statistik Dengan SPSS Versi 11.5, Jakarta, PT. Elex media komputindo, p. 67.

29. Sargent, T.J. (1976). "A Classical Macroeconometric Model for the United States," Journal of Political Economy 84, no. 2 (Apr., 1976): 207-238.

30. Sowa, N. \& Kwakye, J.K. (1993). Inflationary trends and control in Ghana, AERC research paper 22, Nairobi: African Economic Research Consortium. .

31. Taylor, M.P. (1987). 'On the long run solution to dynamic econometric equations under rational expectation', Economic Journal, Vol. 97, no. 385, pp. 215-218.

32. Dirk Willem te Velde \& Morrissey, O. (2003). Do Workers in Africa Get a Wage Premium if Employed in Firms Owned by Foreigners?, Journal of African Economies, Volume 12, Issue 1,Pages 41-73,

33. Végh Gramont, C.A.G, Calvo, G., \& Reinhart,C. (1994). "Targeting the real exchange rate: Theory and Evidence" Journal of Development Economics, Vol. 47, 1995, pp. 97133.

34. Wallis, K.F. (1969). 'Some recent developments in applied econometrics: dynamic models and simultaneous equation systems', Journal of Economic Literature, Vol. 7, No. 3, September, pp.771-796.

35. Westaway, \& Peter F., (2000). Economic Models at the Bank of England. Bank of England Quarterly Bulletin, November 2000. Available at SSRN: https://ssrn.com/abstract=764409: 